\title{
SEMIOLOGICAL ASPECTS OF MUSICAL INSTRUMENTALISM
}

\section{Chernoivanenko A. D.}

\section{INTRODUCTION}

When the German scientist G. Helmholtz wrote in the second half of the XIX century that "the information of natural science, philosophy and the arts have evolved separately in recent times more than it should" , he actually predicted the development of musicology in the XX and XXI centuries. A similar point of view was shared by other research musicians. Therefore, it is no coincidence that a characteristic feature of musical science in the future was the consideration of musical laws from the point of view of other sciences in the aggregate of their approaches and methods, which, perhaps, was a way of rapprochement, recreation of the once lost unity. Musicology has revealed patterns representing an alloy of various types of spiritual and scientific activities of man, such as music and physics (G. Helmholtz, J. Tyndall, L. Termen, V. Sperantov, N. Garbuzov, Y. Rags, N. Morozov and others), music and mathematics (G. Riemann, A. Fort, M. Babbit, J. Run, B. Yavorskyi, A. Losev, G. Konyus, Y. Kholopov, E. Nosina and others), music and architecture (E. Praut, G. Konus, J. Xenakis, B. Galeev, etc.), music and philosophy (K. LevyStrauss, A. Losev, M. Bakhtin, E. Anserme, M. Arkadiev, L. Mazel, I. Pyaskovskyi, V. Sukhantseva, A. Samoilenko and others), music and philology, linguistics, textology (R. Westphal, F. de Saussure, M. Bakhtin, M. Aranovskyi, V. Kholopova, A. Samoilenko, etc.), music and psychology (G. Schenker, V. Wundt, G. Fechner, T. Ribot, K. Stumpf, L. Vygotskyi, B. Teplov, G. Kogan, E. Nazaikinskyi, V. Medushevskyi, A. Samoilenko, etc.), etc.

Semiotics, or, in the interpretation of F. de Saussure, semiology is a modern humanitarian meta-science that considers any phenomena or objects as significant. Today it is an important component of this fusion of sciences, enriching modern musicology with new facets of discovering musical meaning. Moreover, in such a non-verbal-sign system as musical and instrumental art. Semiotic problems allow us to consider its sound organization, shaping, texture, instrumental organology, etc. from broad positions, to attract the provisions of this science in the field of musicology.

${ }^{1}$ Гельмгольц Г. Учение о слуховых ощущениях как физиологическая основа для теории музыки. СПб., 1875. С. 1. 
The appeal to semiology in the field of instrumental organology, music and performance is deeply logical and is associated with the general cultural processes of the XX and XXI centuries as a whole. Artistic practice itself directs theoretical musicology into the field of semiotics, since from a semiotic point of view, musicology "is nothing more than an interpretation of a musical system using a verbal language (as a universal sign system capable of interpreting any social phenomenon, any communicative process)" ${ }^{2}$.

Returning to the topic of musical instrumentalism as an object of semiotic research, we can anticipate the correctness of the formulation of the problem of semiotic processes not in a musical composition in general, but in a more local area related to musical instrumental organology, morphology, performance, etc. From our point of view, an appeal to semiology is justified here, since the inclusion of semiotic parameters in the indicated areas of the musical and instrumental culture creates the necessary qualities of wholeness and comprehensive meaningfulness. Like a verbal language, a musical and instrumental organization, being an expression of musical thought, is clothed not only in certain grammatical, figurative and sound, associative-historical, performing and psychological and artistic forms, which are distinguished by aesthetic perfection, but also is a medium of information that serves as a way of communication.

Thus, the semiotic approach to the study of musical instrumentalism seems relevant, as it is dictated by the needs of modern performing and composing practice, musical psychology and performance theory, contributing to the development of their cognitive aspect. The semiological perspective of the study will allow us to take another step towards the development and knowledge of instrumental art, not only from the standpoint of logical organization, but also from the point of view of meaningful, communicative aspects.

\section{The justification of semiotic aspects of musical instrumentalism study}

Semiotics as a special discipline formed in the 70s of the XX century (the first International Congress on Semiotics took place in 1974), although at the level of methodology the science of sign systems actually functioned already in the 60s (in 1964 were published "Lectures on structural poetics", written by Y. Lotman; in 1965 - "Fundamentals of Semiology" by R. Barth, in 1968 - the first edition of "The Absent Structure" by U. Eco). Born at the intersection of structural linguistics, information theory and cybernetics, personally representing the "space of translation from the language

2 Зильберт Б.А. Семиотический язык музыки (в развитие идей Б.Л. Яворского). Венок Яворскому: Международный сборник научных статей первых международных Научных Чтений, посвященных Б.Л. Яворскому (25-26 ноября 2003 г.). Саратов, 2003. С. 56. 
of philosophy to the language of science and vice versa" ${ }^{3}$, semiotics managed to quickly "infiltrate" other sciences, in particular, art and musicology, which needed at that time new methods of research and interpretation of actively transforming and emerging new postmodern language means. Being a kind of "classification of discourses" ${ }^{4}$, semiotics at the same time builds local trends within these sciences and in a certain way claims to be a peculiar sum of humanitarian knowledge that can describe and explain any (discursive) phenomenon (as a desire for a single common language - metalanguage). The latter, however, remains a claim, as it was, for example, with medieval scholasticism. Not without reason, starting from C. Pierce and C. Morris, scientists noted a parallel between the three sections of semiotics (syntactics, semantics and pragmatics) and the scholastic Trivia (grammar, dialectics and rhetoric, respectively). After all, as you know, a sign system always reveals syntactic (intersystem), semantic (communication of a sign system with the outside world) and pragmatic (between the sign system and the user of this system) relationships, acting as a "delimited set of sign elements with a system of relations between them, which is capable of forming connections with the context, and can also be used by the interpreter" ${ }^{5}$.

In general, various philosophical and scientific schools (psychoanalysis, logical positivism, cognitive science, synergetics, etc.) sought to develop a unified metalanguage. Semiotics here differs favorably from them in the fact that its interests are focused on the language itself, and not on experience. These schools are "distracted" by empirical data (and at the same time can and do make some language "mistakes"); they come to contradictions in their own discourse, thereby shaking their own methodological basis. In semiotics, this effect (or defect) of the mismatch is mitigated precisely by the freedom of interpretation, since there is no strict dependence on the world of facts (as, for example, in synergetics). It is the interpretative nature that allows semiotics to naturally and fruitfully "take root" in musical art, especially in such a non-verbally interpreted as instrumental.

The desire to build a single consistent, methodologically impeccable theory is, according to scientists ${ }^{6}$, the "innate idea" of culture. Thus, culture saves itself from entropy. The concept of the universe as a semiosphere, a semiotic whole is one of the mechanisms of self-defense from one's own polyphonic multiplicity, which can "digest" and destroy it. However, the semiotic doctrine itself is far from theoretical and methodological completion.

3 Шелковников А.Ю. Философия семиотики как метагносеологическая проблема: автореф. дисс.. д-ра филос. наук: 09.00.01. Москва, 2006. С. 6.

${ }^{4}$ Ibid. C. 12.

${ }^{5}$ Ibid. C. 8.

${ }^{6}$ Ibid. C. 13. 
In the second half of the XX century, musical avant-garde, on the one hand, and the development of semiotics, on the other, stimulated debate about the ability of music to express a specific meaning with concrete means. The juxtaposition of points of view - music as an asemantic reality and as a system of signs - reached a very sharp confrontation. And although, on the whole, the idea of music as a means of special - artistic - communication was more convincingly affirmed, the mechanism of musical communication and the nature of musical significance remained and remain relevant research objects. And if in vocal and instrumental genres the verbal text determines or contributes in many ways not only to the formation of a holistic meaning, but also to purely musical intonations, then the communicative and semantic aspects of the musical and instrumental "message" imply the presence of a certain sign system.

The semiotic aspect is a kind of attempt to translate non-verbal musical instrumental messages into the language of human communication, which is accompanied by a "decrease in uncertainty and an increase in communicativeness" ${ }^{7}$. he cited quote by Y. Lotman refers to the field of human sleep, not instrumental music. However, comparing sleep and music "retelling a dream is as difficult as, say, retelling a piece of music in words" ${ }^{8}$ the scientist precisely conveys one of the characteristics of "pure" instrumental art. After all, "music remains self-sufficient and without any word" ${ }^{9}$. In this way, V. Kholopova emphasizes the power and specificity of "absolute music" (a German term of the XIX century; Russian musical thought preferred the expression "pure, non-programmed instrumental music"). However, the very concept of "absolute music" with the philosophization inherent in German science at one time raised the Beethoven-type symphony to the highest level of musical and artistic hierarchy, confirming the thesis that the instrumental culture itself is music as such (note that the differentiation of the already autonomous quality of music on vocal and instrumental is reflected in popular terminology as the opposition "music - singing": people call purely instrumental music making as "music" ${ }^{10}$ ). And here the semiotic principles of thinking and perception turned out to be a necessary intermediary between creators, performers (at the dawn of the formation of "pure" instrumentalism, these positions were combined in one person) and the listeners. Purely musical intonational (rhythmic, sonic, melodic, fret, textured) structures become carriers of meanings, ideas, and their signs (such modal signs can already be discussed in the doctrine of frets in ancient Greek music). On the whole, the

${ }^{7}$ Лотман Ю.М. Семиосфера. СПб.: Искусство, СПБ, 2004. С. 125.

${ }^{8}$ Ibid. C. 726.

${ }^{9}$ Холопова В. Феномен музыки. М.: Директ-Медиа, 2014. С. 192.

10 Мациевский И. Народная инструментальная музыка как феномен культуры. Алматы: Дайк-пресс, 2007. С. 92. 
ancient Greek understanding of music as a science created the prerequisites for turning the first to semiological principles in the last third of the XX century: "The new level of civilization, reached by the ancient Greeks through the verification of music by numbers, was that they tore music and "musical arts" from intellectual activity their primitive, archaic magical and ritual functions"11. Through numbers and proportions, philosophers and musicians sought to express the laws of the universe, harmony. And the music here acted as a clear and audible embodiment of this numerical perfection of the world as a practical art (tuning strings, intervals, rhythms, frets) and as a science (theoretical calculations of high and rhythmic proportions). In the Platonic theory of the similarity of seven planets and musical intervals on a string, in the numerical understanding of music, those instrumental signs of the word "music" itself were formed. They have been preserved for more than two thousand years. And if the era of European Baroque with its enthusiasm for the transfer of "soul movements" in music (but also verified rhetorical figures), like romanticism with the undivided dominance of "aesthetics of feelings" (but also with its own signs of "sigh", "sadness", "heroics”, "love”, "paths", etc.), proclaimed a departure from the mathematical approach, then the XX century put forward the problem of finding new rational composition systems that could no longer do without numerical calculations; the heyday of intellectualism in art; use of fundamentally new technical means.

Brought to perfection during the XVII and XX centuries, "the emotional possibilities and high logical interconnections of all elements of music" (V. Kholopova) allowed this kind of art to convey with its "wordless language" even that "it could not be expressed in the form of philosophical ideas"12. Beethoven became the founder of such a development of music pure non-programmatic, non-verbal instrumentalism. However, the emancipation of music actually occurred in the era of J. S. Bach, although "did not become noticeable here, since Bach surrounded it with a" veil of verbal emblems" $^{13}$. About the era of the XVII century, U. Eco pointed out that the symbols here were not just a rhetorical background of a person's life, but were conceived by him as a true reality: "People of that century considered it a duty to transform the world into a thicket of Symbols, Masquerades, and Paintings. Everything should reflect secret connections, be a treasury of meanings, tell a lot, but quietly, withhold more than open. The mystery of the symbol (the limit of limits) is volatile, like a dove, slipping away, and it is never known where it is. But to dream about what is obviously not given, is not this the peak of the

${ }^{11}$ Холопова В. Российская академическая музыка последней трети ХХ - начала XXI веков (жанры и стили). Москва, 2015. С. 8.

${ }^{12}$ Холопова В. Феномен музыки. М.: Директ-Медиа, 2014. С. 23.

${ }^{13}$ Ibid. C. 98. 
noblest desires?”14. It is no wonder that it was precisely in such an era that a new musical and instrumental art was born, capable of embodying pure meanings with new linguistic means, building on their basis a new type of communication between the musician and the listener. The main discoveries of musical baroque are the birth of opera; formation of an instrumental concert; emancipation of concert halls; emotional impression of affects; energy of motor movement - led to a historically new concept of "music". All of them are largely formed in instrumental ("absolute") music.

The key idea of the latter was the emancipation of musical instrumentalism and the new opportunity for the embodiment of the Absolute associated with its specificity and means of expression. For the XVII century, the tendency of the projection of vocal music on instrumental (double mimesis), in particular, in the field of rhetoric, is indicative. So, L. Pylaeva quotes the French harpsichordist de Saint-Lambert: "The examples of eloquence are like a musical play, because the harmony, rhythm, measure, size and other similar things that a skillful speaker adheres to in composing his

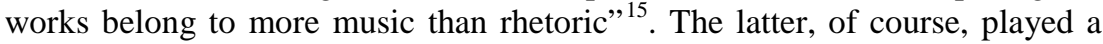
crucial role in the formation and development of instrumental music forms (however, we, following Dalhouse, indicate that here we should refrain from too straightforward analogies).

So flexible, in our opinion, we ought to approach the issue of the music origin. Recognizing the inextricable connection of instrumental play with the word, it should be noted that instrumental music-making is "originally associated with vital processes ... as well as ritual rites ... with hiding the human voice", which makes the instruments themselves, performing them and playing music performed on them recognizable "iconic carriers". A similar sign - the "non-verbal translation system" - works beyond the "limits of the actual labor experience"16 and ritual actions. The ripening of music "from non-music" I. Zemtsovskyi sees "not only as a "mechanical" process of isolating and expressing a musical instrument", but also as the formation of a new quality: "It can be argued that historically a musical instrument is ... some new, mutually transient synthesis, a kind of new, non-casual thinking, finally"17. The researcher sees this new quality in the genetics of musical instruments as "simultaneously a gesture separated from the body and a sound separated from the mouth"18.

14 Эко У. Остров накануне. СПб.: Symposium, 1999. С. 331-341.

${ }^{15}$ Пылаева Л. К вопросу о соотношении и взаимодействии французских и немецких традиций в риторике музыки барокко. Старинная музыка. 2013. № 3 (61). С. 12.

16 Мациевский И. Народная инструментальная музыка как феномен культуры. Алматы : Дайк-пресс, 2007. С. 7.

${ }^{17}$ Земцовский И. Музыкальный инструмент и музыкальное мышление (к постановке вопроса). Народные музыкальные инструменты и инструментальная музыка: в 2-х чч. М., 1987. Ч. 1. С. 127.

${ }^{18}$ Ibid. 
N. Mechkovskaya claims that gestures and facial expressions are the closest to nature from human semiotics, because they "underlie those physical movements and actions that make up the effectively-figurative filling of such languages of mankind as ritual, dance, acting" ${ }^{19}$. This list can be supplemented with music as the most difficult-to-decode semiotic language system, especially in the field of so-called "pure" instrumental music - directly, without involving the word (and unnecessary "translation" into another sign system) transmitting "pure meanings" - thoughts. In music making (as well as in the development of human intellect as a whole), the hand participates on a par with the voice, and it is it that produces the sound on the instrument. According to Asafiev, "the process of ... intonation, in order to become not speech, but music ... bypassing the word (in instrumentalism), but experiencing the influence of "silent intonation" of plasticity and human movements (including the "language" of the hand),... becomes a "musical speech", "musical intonation”" ${ }^{20}$ And, further, "a man’s hand as if can "put his voice" into instrumental intonation" ${ }^{21}$. The hypothesis of K. V. Kvitka that primitive man, drilling holes on a flute, took into account only optical (rather than acoustic) symmetry deserves attention.

"Probably the primitive master was not worried about exactly what intervals he would receive on his instrument; he enjoyed the presence of different sounds ... those sounds that were obtained and, as a result of it, were considered beautiful ... Only rumor was gradually included in this matter"22.

The oldest of these mankind languages is a ritual (where musical instruments were also actively used), and the most ancient component in the ritual is a symbolic physical movement. However, first of all, it's temporal (and to be precise, spatial and temporal), the art of music is directly related to movement - one of the primary semiotics of man. In musical instrumentalism, in addition to the semantic processuality of deployment, the development of a musical idea (or even a separate sound-image, sound-symbol) and means of expressiveness (melody, rhythm, texture, dynamics) - the movement becomes visually tangible, typological or improvised unexpectedly; finally, it is associated with the method of sound production and sound science. And not only in a concert-stage or folklore setting, where attention is specifically directed to these forms of movement. The semiotic parameters of movement with a musical instrument in hand, even in the process of ancient ritual (often requiring mystical concealment of the human voice), labor or leisure activities, as well as performing forms of movements on the instrument (directly

19 Мечковская Н.Б. Семиотика Язык. Природа. Культура: Курс лекций учеб. пособие для студ. филол., лингв, и переводовед. фак. высш. учеб. заведений. 2-е изд., испр. М. Издательский центр «Академия», 2007. С. 178.

${ }^{20}$ Асафьев Б. Музыкальная форма как процесс. Л.: Музыка, 1971. С. 211-212.

${ }^{21}$ Ibid. C. 216.

${ }^{22}$ Квитка К. В. Избранные труды в двух томах. М., 1971, т. І. С. 221. 
for sound extraction), are enriched by sound impressions (on drums - timbre and rhythmic, on strings and winds - also timbre-pitch, motive and melodic, frets, etc.), forming a new layer of already sound semiotics (or new syncretic formation of sound movement) with its own sign system. In addition, it is known that musical (rhythmic-pitch, dynamic, articulatory) expressiveness largely models the plasticity of human movements, as well as the kinesthetic activity of speech, etc.

In the course of historical development, the indicated sound semiotics in its timbre and instrumental, rhythmic, intonational-pitch, fret, motive and melodic expressions, preserved in associative-sound memory, can indirectly or even directly influence the figurative and sound representations of subsequent eras, including the samples of "pure music". For example, the sound of brass instruments is often associated with images of heroics, military prowess, triumphant apotheosis; hunting / "forest" mythology; holidays rituals, and subsequently, as a result of new associative series of developing professional musical art (folklore and academic) - and with tragic, fantastic, grotesque characters, pop-jazz spheres.

Woodwinds more often embody the images of an idyllic pastoral, fairy-tale, fantasy, play, character of motor or lyrical utterance, etc. At the same time, living breathing, which is the basis of sound production for all winds, can symbolize both the earthly human life principle ("breath of life", "earth"), and the otherworldly, mystical, supernatural, spiritual Being ("breath of heaven"). It is not for anything that this method of sound production lays at the heart of the "king of instruments" - an organ that is officially allowed to praise God in a Catholic church next to the "angel voices" of the choir. In addition, blowing the air stream as the "breath of life", "spirit", the performer on the winds animates, mythologizes, personifies his instrument, which as a result becomes able to "speak" an otherworldly, unearthly, inhuman "voice" (which clearly demonstrates participation in the sound production of the ear-cushion apparatus by analogy with human speech and the impossibility of using the voice simultaneously), showing the listener or other participants in the action (as well as the performer himself) a specially encoded idea, symbol.

Plucked instruments (plucked chordophones), genetically associated with both singing and dancing movements, organologically having chamber sound and certain mobility, are associated, respectively, with ritual and secular verbal genres (accompaniment of prayer, spiritual, historical-epic or entertaining chants), as well as with bright rhythmically-pitched characteristic of national or genre and dance symbols. Their organological ability to combine rhythmic clarity in the arrangement of accentuations (like percussion) with high-altitude parameters necessitated their creation and existence among almost all peoples of the world. 
Stringed bow (frictional chordophones), which are a product of a relatively later culture of the East (from about the VI century) ${ }^{23}$, were originally used only for playing melodics, smooth strokes exclusively as an attribute of the ritual and ceremonial sphere as a means of magical influence, an intermediary between the divine world and $\operatorname{man}^{24}$ (motor-articulation techniques with light "jumping" strokes became available in fact only with the improvement of the bow of G. Tartini in 1730). Improvement and modernization of instruments and bows, as well as the nascent new chamber and instrumental performance, allowed stringed chordophones to come closer to the sound of a human voice as compared to other instruments, having formed a sensually-reverent sound image of a high lyrical order in a relatively short history of its existence and, at the same time, brilliant concert virtuosity as a vital energy and beauty of movement and aspiration.

Complicated (in the sense of organology and in the sense of using more recent experience) keyboards that appeared as a result of synthesizing the possibilities of an ensemble instrumental game of different compositions, stably tuned, as a rule, spatially large and stationary (except for the accordion accordion), were originally addressed to a nonrandom audience and circle performers. They are an example of developed musical and instrumental professionalism with traditions of training and performance, spatial and sound thinking of a polyphonic texture, managed by one performer.

All of these instruments, from folklore (signaling, leisure, labor) to sophisticated academic ones, for the performer and composer (and often for the listener) are a sign of music itself.

\section{Anthropological and mythological symbolism of musical instrumentalism}

Returning to the idea of I. Zemtsovskyi on musical instrumentalism as the birth of a new quality of thinking, as a symbol of gesture and sound separated from human physicality, let us turn to semiological categories. So, a sign is not just a trace of a referent (and a person generally deals with signs more often than with referents). The sign represents the referent as "text", where "information about the replacement object has a different degree of folding or deployment" ${ }^{25}$. The referent, according to Pierce, is displayed in the mode of tertiary, where the sign, separating and moving away from what it replaces, gets meaning; not just used instead, but "creates the image of the

${ }^{23}$ Демин А.Г. Монгольские смычковые инструменты, их роль и место в культуре народов Центральной и Восточной Азии: автореф. дисс ... канд. ист. наук: 07.00.07. УланУдэ, 2000. С. 18.

${ }^{24}$ Ibid. C. 16.

${ }^{25}$ Бразговская Е. В лабиринтах семиотики: Очерки и этюды по общей семиотике и семиотике искусства. Москва; Екатеринбург: Кабинетный ученый, 2018. С. 29. 
referent from the point of view of man, tradition, culture" ${ }^{26}$; makes it possible to look at the displayed from a different angle: to see a certain symbolic image. A musical instrument as a "continuation" of a hand, an ear cushion with ligaments (in the winds), the entire human body (as in a piano or organ), "detaching and moving away", allows a person to more accurately study in more detail, more objectively at a distance from the "side view" of yourself. At the same time, when playing an instrument, there is no complete separation from the instrument, the performer, in the process of translating thought and feeling into an instrumental sound image, tactilely, acoustically and visually directly - feels such a translation as his statement. The instrument, created "in the image and likeness" of a person, helps to identify and manifest various supra-human (desired, magically enhanced) possibilities - breath lengths, virtuoso motor skills, polyphony in a single thought-performing center ("person and orchestra"), sound range, dynamic parameters, strokes, sonoristic components, melodic sophistication (for example, "jumping”, "non-singing” structure), etc. - those techniques and means that are usually called instrumental due to their increased complexity or the impossibility of their implementation by the human voice. Thus, it is the way of representing the referent that becomes the basis for the categorical distribution of signs (index, icon or symbol) and, most importantly, a tool for generating meanings.

But musical instruments that are capable of generating meanings without words, so to speak, directly outgrow the status of the mark, becoming actually "The Other" (according to Y. Lotman; it is interesting that B. Asafiev wrote: "When the instrument was like the voice of its "owner", it "Second Me"..." ${ }^{27}$ ), capable of engaging in dialogue, offer their own "themes" or means, transforming such a dialogue or even directing it. Instrumental music today has actually come to such a state of affairs when textured, articulatory-dynamic, timbral and other features and characteristics of musical instruments "dictate" to the composer the development of dramaturgy, and not just the choice of means of its embodiment. This situation corresponds in a certain way with Lotman's understanding of the self-development of culture in the context of the structural and semiotic concept as a dialogical process in which the presence of "The Other" is the leading condition for the emergence of new cultural codes. A musical instrument like "The Other" becomes capable of creating new musical and language codes both in a certain type of culture (national, stylistic, including individual stylistic, epoch-making, etc.), and outside it.

I. Zemtsovskyi (legends of self-playing pipes, for example) indicates the self-activity of musical instruments (as well as others) created by man. The tool initially hides in itself more than a human creator invested in it at a conscious

${ }^{26}$ Бразговская Е. В лабиринтах семиотики: Очерки и этюды по общей семиотике и семиотике искусства. Москва; Екатеринбург: Кабинетный ученый, 2018. С. 29.

${ }^{27}$ Асафьев Б. Музыкальная форма как процесс. Москва, 1971. С. 253. 
level. And such "hidden secrets" of the instrument are an important non-verbal source of music in general and one of the reasons for its personification. The "continuation" of speech in the instrument gave rise to "antirecision", and the "continuation" of the body - "antibody" (for example, instruments made of bones). In fact, such an "anti-speech" became "absolute" music and music in general, as that which distinguishes musical language from verbal.

Lotman wrote that it was outside the text, outside the type of culture, where encoding and decoding devices lay. With regard to musical instrumentation, one can quote such an example. All nations have their own tanning instruments (plucked with fingerboard), as it is them, according to M. Imhanitskyi, who are the most adapted (at least in their folklore, not modernized in accordance with the requirements of professional composer creativity, in the form) to a clear, with a variety of accentuation, performance of rhythmic structures enriched in high-pitched (compared to percussion). Such an expressive accentuation of the tanning (primarily in leisure and ritual dance forms of expression) makes it virtually impossible to determine the primary plucking of certain peoples. At the same time, the synthesized (sharpening the expressiveness of perception) rhythmic and sound-pitch feature actualizes the need for such instruments.

Returning to the origins of musical instrumentalism as a whole, it should be noted that a musical instrument, like "The Other", embodied a certain "magical" synthesis (polyfunctionality) of sound, visually graphic, sensuallytactile and ideal (meaningfully intonated) principles, languages and "thoughts" (which, however, historically did not develop in isolation from each other). This "coincidence of the incorporeal (that is, intonation) and the bodily (instrument, configuration, movement; formation of the system: "instrument - body instrument, etc.)" 28 , in fact, allows the instrument to rise to "The Other".

Apparently, this gives rise to mythological ideas about a certain "magic miracle" of a musical instrument, a "self-playing" phenomenon - an instrument that seemed to be a living being, personified. So, I. Zemtsovskyi speaks of Indians and Africans who fed their sacred drums, introduced them to each other, etc. 29 Numerous examples of such personification are contained in myths, fairy-tales, ballads, songs. In the Sumerian-Babylonian kingdom, even sacrifices were performed in honor of musical instruments.

"The motives of musical instruments constitute an essential and largely determining part in any system of musical images: both in mythology and literature" 30 - we continue the thought of L. Herver - also in philosophy,

${ }^{28}$ Земцовский И. Музыкальный инструмент и музыкальное мышление (к постановке вопроса). Народные музыкальные инструменты и инструментальная музыка: в 2-х чч. М., 1987. Ч. 1. С. 127.

${ }^{29}$ Ibid.

30 Гервер Л. Музыка и музыкальная мифология в творчестве русских поэтов (первые десятилетия XX века). М.: Индрик, 2001. С. 67. 
music itself and human life. Motives and images of instruments mediate "between modernity and the archaic past - just like real instruments that have preserved the basic principles of sound production and a whole series of names from immemorial time" ${ }^{31}$. Thus, the instrument acts as a special form of communication and at the same time being of people of past, present and future cultures in a semiological context.

Moreover, the "body", the materiality of the instrument - its shape, material, manufacturing method, as well as the features of the previous "existence" are not less important than its sounding qualities. The functions of the instrument are far from exhausted by the aesthetic sphere (in many mythologies, it is practically not indicated). Much more significant in myths is the inclusion of the instrument in the harmony of the world order, participation in the ritual, and magical properties. Thus, the musical instruments themselves (both a general category and specific samples) acquire symbolic meaning, act as symbols, "images taken in the aspect of their symbolism" and "signs endowed with all the organicity of the myth and the inexhaustible polysemy of the image ... the symbol category emphasizes ... "the image goes beyond its own limits, in the presence of a certain meaning, intimately merged with the image, but not identical to $\mathrm{it}^{\text {" }}{ }^{32}$. It is this meaning that we have in mind when speaking about the symbolism of musical instruments. Indeed, by "mating" an object and meaning, a symbol at the same time "mates" people who "love and understand this meaning, contributing to the integrity of consciousness ... ultimately, the content of a genuine symbol through mediating semantic links is always correlated with the "most important"- with the idea of the world totality, with the fullness of the cosmic and human "universe" ${ }^{33}$ ". Nowadays, in connection with the concept of "neomythological consciousness", with the awareness of culture history as "an essential part of human symbolism history" 34 , the understanding of the symbolic meaning of musical instrumentalism largely explains the fact that it is instrumental culture that becomes the focus of ideological and figurative and linguistic searches in music.

A musical instrument enters into a relationship of transformation and identity with all elements of the mythological world and with the world itself: in this sense, each characteristics of the instrument is not unique. So, "an instrument is isomorphic to man and may be his incarnation. The isomorphism of man to the cosmos, organized by world space, which, according to some

31 Гервер Л. Музыка и музыкальная мифология в творчестве русских поэтов (первые десятилетия XX века). М.: Индрик, 2001. С. 67.

32 Аверинцев С. Символ. Аверинцев С. София-Логос: Словарь. 2-е, испр. изд. К.: Дух і Літера, 2001. С. 156.

${ }^{33}$ Ibid.

34 Аверинцев С. К уяснению смысла надписи над конхой центральной апсиды Софии. Древнерусское искусство и художественная культура домонгольской Руси. М.: Наука, 1972. 
ideas, came from the members of the body of the first man, also provides an isomorphism or identity between the world and a musical instrument" ${ }^{35}$.

The anthropomorphism of musical instruments is expressed through the similarity between the structure of the human body and a musical instrument. It is known that often in the folk tradition the proportions and sizes of musical instruments were measured according to a person, and in the modern European instrumental dictionary there are such names of parts as the head, neck, tongue, leg, knee, pen, beak, wing, etc. The belonging of the instrument is directly related to its aim - those or other ritual functions that were carried out through a musical play. The functioning of a musical instrument in the ritual is one of the obligatory motifs of ancient mythologies. Thus, a musical instrument as a symbol embodies a higher, spiritual meaning.

In myth, the sound of a musical instrument is often associated with creation, world order, and consent. Playing a musical instrument brings order and harmony, serves the construction of the world. The myth of Amphion tells about the construction of the walls in Thebes with the help of the game on the lyre $^{36}$, that is, about the organization and creation of space with the help of an instrument from undivided chaos. No wonder the destruction of city walls (Troy, for example) corresponds to the destruction, disappearance of the city as a small space. Hence there is the motive for tuning a musical instrument, which is understood as restoring order and harmony. Violations of musical harmony can cause various disasters ${ }^{37}$.

Interestingly, in the "new mythology" (for example, poetry of the $\mathrm{XX}$ century), as the indicated symbolism continues, a new one appears. In Russian poetry of the early XX century "references to ancient (especially Greek) plots are combined with mythological "discoveries". The most important feature of the new mythology can be considered the predominance of the motives for the revitalization (or initially "living") of musical instruments, while for the traditional mythological motifs the opposite direction of transformation is typical: from nature to culture, from living to nonliving”38. The new mythology is characterized by the motives of double being, symbols of the perfect balance of nature and culture. Now, in order to "become" a musical instrument, it is not necessary to die. So, "Hlebnikov's goblins" "pull hair from a brow and play like a harp, with a horse hoof", mermaids play "harp of braids" 39 .

35 Гервер Л. Музыка и музыкальная мифология в творчестве русских поэтов (первые десятилетия XX века). М.: Индрик, 2001. С. 68.

36 Иванов В. Возникновение трагедии. Архаический ритуал в фольклорных и раннелитературных памятниках. М., 1988. С. 238.

${ }^{37}$ Виноградова Е., Желоховцев А. Китайская музыка. Музыкальная энциклопедия: в 6-ти томах / гл. ред. Ю.В. Келдыш. М.: Советская энциклопедия, 1976. Т. 2. Стб. 807.

38 Гервер Л. Музыка и музыкальная мифология в творчестве русских поэтов (первые десятилетия XX века). М.: Индрик, 2001. С. 73.

${ }^{39}$ Ibid. 
The zoomorphism, inherent in many instruments and enshrined in the dictionary of instrumental terminology, seemed to concentrate in the piano with "key teeth (V. Mayakovski), "with fibrous wooden meat, gold veins and always inflamed bone" (O. Mandelstam). Such characteristics of instrumental sounding as "voice", "crying", "groan" refer to mythological subjects, recalling, for example, about a reed pipe that grew on the grave of the victim: the pipe sings and cries with its voice. This singing, speaking sound of a musical instrument is evidence of its anthropomorphism. This is the highest praise, essentially equating the instrument created by the hands of man to man, the crown of creation. It is appropriate to recall the attitude of performers, including modern ones, to their instrument as a living being. In the $\mathrm{XX}$ century, the personification of musical instruments is also expressed in the appearance in the artistic language of literature, theater and cinema materialized metaphors ("Rehearsal of the orchestra" by Fellini, "Double bass" by Susskind). In the "new mythology" (for example, Belmont and Blok), emphasis is placed on the "mythology of sound, voice, the source of which is sometimes not only invisible, but also unknown" ${ }^{40}$. Sound is understood as a symbol. Naturally, therefore, that the main thing in sound is its semantic content, and not, for example, pitch, duration, and even timbre. Thus, the poetry of the early XX century "prophesies" the output of the sounds to music of the second half of the century - sonorics, which became the subject of serious musicological reflection only in recent decades.

\section{CONCLUSIONS}

Artistic work (in music - composer and performer), as well as its result, is a work of art. It acts as systemically organized, interpenetrating and interdependent semiotic structures that require special analysis. However, not less complex communicative, creative, and specifically musical systems are the musical instruments itself, as well as systems that include different combinations such components as a performer, instrument, composer, and listener.

We carried out the musicological characterization of musical and instrumental semiology on the basis of a "generative device", which is a semantic system, the components of which can be mental, material sensory and timbre and sound, historical, philosophical, anthropological and mythological spheres. All of them work in the mode of long-term memory and sign-communicative interaction. Moreover, this device is capable of encoding, producing mental values, both in discrete and in continuous form.

The sign, which is fundamental for semiotics, in the musical and instrumental art covers not only intonation, means of expression (composing and performing, stable and mobile), etc., but also the musical instrument itself,

${ }^{40}$ Гервер Л. Музыка и музыкальная мифология в творчестве русских поэтов (первые десятилетия XX века). М.: Индрик, 2001. С. 74. 
with its timbre, articulatory-dynamic and textural capabilities, organological parameters, historical conditions of existence and development, genre and stylistic traditions and priorities, performing forms of the play.

A musical instrument as a "continuation" of a person (bodily and ideally absolute in its non-verbal translation of meaning), "separating and moving away" (C. Pierce about a sign), allows a person to better understand and comprehend himself and the world at a distance from a "side view" in dialogue with "The Other" tool. Thus, representation (referent, thoughts, ideas, images) in musical instrumental terms becomes a means of generating meanings without words, and the instrument itself becomes a "second self" (performer and composer), i.e. "The Other" - the one that is able to engage in dialogue, propose its "topics" or means, adjusting the dialogue or even directing it. In such a dialogue, a musical instrument is personified, "comes to life”, becomes even more like a living being.

In the process of translating thought and feeling into an instrumental sound image, the performer tactile, auditory and visual - directly - perceives it as his utterance of an absolute order, freed from the verbal sign. The instrument, created "in the image and likeness" of a person, helps to identify and manifest "superhuman" (desired, magically enhanced) possibilities - breath lengths, virtuoso motor skills, polyphony in a single thought-performing center ("person and orchestra"), sound range, dynamic parameters, strokes, sonoristic components, melodic sophistication (for example, spasmodic, "non-singing" structure), etc. - those techniques and means that are usually called instrumental due to their increased complexity or the impossibility of their implementation by the human voice.

\section{SUMMARY}

The article analyzes the problems of instrumental organology, music and performance from the point of view of semiology. It is proved that the musical and instrumental organization, being an expression of musical thought, is clothed not only in certain grammatical, figurative and sound, associative-historical, performing and psychological and artistic forms, which are distinguished by aesthetic perfection, but also is a medium of information that serves as a way of communication. The sign, which is fundamental for semiotics, in the musical and instrumental art covers not only intonation, means of expression (composing and performing, stable and mobile), etc., but also the musical instrument itself, with its timbre, articulatory-dynamic and textural capabilities, organological parameters, historical conditions of existence and development, genre and stylistic traditions and priorities, performing forms of the play.

A musical instrument expression becomes a means of generating meanings without words, and the instrument itself becomes a "second self" 
(performer and composer), i.e. "The Other" - the one that is able to engage in dialogue, propose its "topics" or means, adjusting the dialogue or even directing it. In such a dialogue, a musical instrument is personified, it "comes to life". In the process of translating thought-feeling into an instrumental sound image, the performer tactile, auditory and visual - directly - perceives it as his utterance of an absolute order, freed from the verbal sign. An instrument created "in the image and likeness" of a person helps to identify and manifest the "superhuman" possibilities of those techniques and means, which are usually called instrumental due to their increased complexity or the impossibility of their implementation by the human voice.

\section{REFERENCES}

1. Аверинцев С. К уяснению смысла надписи над конхой центральной апсиды Софии. Древнерусское искусство и художественная культура домонгольской Руси. М.: Наука, 1972. С. 25-49.

2. Аверинцев С. Символ. Аверинцев С. София-Логос: Словарь. 2-е, испр. изд. К.: Дух і Літера, 2001. С. 155-161.

3. Асафьев Б. Музыкальная форма как процесс. Л.: Музыка, 1971. $376 \mathrm{c}$.

4. Берлиоз Г. Критический очерк о Симфониях Бетховена. В. Г. Берлиоз. Избранные статьи. Москва: Музгиз, 1956.

5. Бразговская Е. В лабиринтах семиотики: Очерки и этюды по общей семиотике и семиотике искусства. Москва; Екатеринбург: Кабинетный ученый, 2018. 224 с.

6. Виноградова Е., Желоховцев А. Китайская музыка. Музыкальная энизиклопедия: в 6-ти томах / гл. ред. Ю.В. Келдыш. М.: Советская энциклопедия, 1976. Т. 2. Стб. 708-815.

7. Гервер Л. Музыка и музыкальная мифология в творчестве русских поэтов (первые десятилетия XX века). М.: Индрик, 2001. 248 с.

8. Демин А.Г. Монгольские смычковые инструменты, их роль и место в культуре народов Центральной и Восточной Азии: автореф. дисс. ... канд. ист. наук: 07.00.07. Улан-Удэ, 2000. 19 с.

9. Земцовский И. Музыкальный инструмент и музыкальное мышление (к постановке вопроса). Народные музыкальные инструменты и инструментальная музыка: в 2-х чч. М., 1987. Ч. 1. С. 125-131.

10.Зильберт Б.А. Семиотический язык музыки (в развитие идей Б.Л. Яворского). Венок Яворскому: Международный сборник научных статей первых международных Научных Чтений, посвященных Б.Л. Яворскому (25-26 ноября 2003 г.). Саратов, 2003. С. 44-56.

11. Иванов В. Возникновение трагедии. Архаический ритуал в фольклорных и раннелитературных памятниках. М., 1988. С. 237-293.

12. Квитка К. В. Избранные труды в двух томах.М., 1971, т. I. 284 с. 
13. Лотман Ю.М. Семиосфера. СПб.: Искусство-СПБ, 2004. 704 с.

14. Мациевский И. Народная инструментальная музыка как феномен культуры. Алматы: Дайк-пресс, 2007. 520 с.

15. Мечковская Н.Б. Семиотика Язык. Природа. Культура: Курс лекций учеб. пособие для студ. филол., лингв, и переводовед. фак. высш. учеб. заведений. 2-е изд., испр. М. Издательский центр «Академия», 2007. $432 \mathrm{c}$.

16. Пылаева Л. К вопросу о соотношении и взаимодействии французских и немецких традиций в риторике музыки барокко. Старинная музыка. 2013. № 3 (61). С. 10-15.

17. Холопова В.Н. Российская академическая музыка последней трети XX - начала XXI веков (жанры и стили). Москва, 2015. 227 с.

18. Холопова В. Феномен музыки. М.: Директ-Медиа, 2014. 378 с.

19. Шелковников А.Ю. Философия семиотики как метагносеологическая проблема: автореф. дисс.. д-ра филос. наук: 09.00.01. Москва, 2006. $30 \mathrm{c}$.

20. Эко У. Остров накануне / пер. с итал. Е. А. Костюкович. СПб.: Symposium, 1999. 496 c.

\section{Information about the author:} Chernoivanenko A. D., Candidate of Art, Professor, Odessa National Musical Academy named after A. V. Nezhdanova 63, Novoselskogo str., Odessa, 65023, Ukraine 